\title{
EHMTI-0159. Assessment of functional health and well-being in headache patients: the effect of individual-based physical therapy
}

\author{
J Hirsvang ${ }^{*}$, LS Kroell, N Caspersen, BK Madsen, RH Jensen \\ From 4th European Headache and Migraine Trust International Congress: EHMTIC 2014 \\ Copenhagen, Denmark. 18-21 September 2014
}

\section{Background}

Patients with tension-type headache (TTH) and/or migraine are often referred to physical therapy. Only few studies have evaluated the efficacy of individual-based exercise program.

\section{Aim}

To evaluate the effect of individual-based exercise on functional health and well-being, headache frequency and pain intensity in patients suffering from TTH and/or migraine.

\section{Methods}

During an 18 months period 282 consecutive patients entered an open label uncontrolled study in a multidisciplinary headache centre. Diagnoses were according to ICHD-3 beta. Functional health and well-being were measured by using Headache Impact TestTM (HIT-6), scores ranged from 36 (no impact) to 78 (severe impact). Pain intensity was recorded on an 11-point numeric rating scale(NRS-11), $0=$ no pain; 10 = worst pain imaginable.

\section{Results}

So far, 40 women and 14 men, mean age 39.4 , completed the study. 28 were diagnosed with TTH, 4 with migraine and 22 with both TTH and migraine.

In TTH-patients HIT-6 decreased from 59.6 to 54.4 (p < 0.01 ); frequency decreased from 24.9 to 18.0 days/month $(\mathrm{p}<0.01)$; pain intensity decreased from 5.8 to 3.9 NRS-11 $(\mathrm{p}<0.01)$.

In patients with combined TTH and Migraine HIT- 6 decreased from 61.3 to $58.8(\mathrm{p}=0.06)$; the TTH-frequency decreased from 20.6 to12.6 days/month $(\mathrm{p}<0.01)$, and

Dept. Neurology Glostrup Hospital, Danish Headache Center, Copenhagen, Denmark

(c) 2014 Hirsvang et al; licensee Springer. This is an Open Access article distributed under the terms of the Creative Commons Attribution License (http://creativecommons.org/licenses/by/2.0), which permits unrestricted use, distribution, and reproduction in any medium, provided the original work is properly cited. their migraine frequency from 4.0 to 2.3 days/moth $(\mathrm{p}=$ $0.03)$; whereas pain intensity was uneffected (TTH: $\mathrm{p}=$ 0.09, Migraine: $\mathrm{p}=0.15$ ).

\section{Conclusion}

Individual-based exercise has shown a positive effect on functional health and well-being, headache frequency and pain intensity in severely affected patients especially in TTH and less for combined Migraine and TTH. Randomised controlled studies are needed to confirm these findings.

No conflict of interest.

Published: 18 September 2014

doi:10.1186/1129-2377-15-S1-D29

Cite this article as: Hirsvang et al:: EHMTI-0159. Assessment of

functional health and well-being in headache patients: the effect of

individual-based physical therapy. The Journal of Headache and Pain 2014 15(Suppl 1):D29.

Submit your manuscript to a SpringerOpen ${ }^{\bullet}$ journal and benefit from:

- Convenient online submission

- Rigorous peer review

- Immediate publication on acceptance

- Open access: articles freely available online

- High visibility within the field

- Retaining the copyright to your article

Submit your next manuscript at $>$ springeropen.com 